COMMITTEE REPORT

\title{
METex14 Skipping Testing Guidance for Lung Cancer Patients: The Guidance from the Biomarker Committee, the Japan Lung Cancer Society
}

\author{
Yasushi Yatabe1; Koichi Goto²; Shingo Matsumoto2; Yutaka Hatanaka3; \\ Naoko Arakane4; Sadakatsu Ikeda5; Akira Inoue6; Ichiro Kinoshita7; \\ Hideharu Kimura8; Tomohiro Sakamoto9; Miyako Satouchi10; Junichi Shimizu11; \\ Kuniko Sunami12; Koji Tsuta13; Shinichi Toyooka14; Kazuto Nishio15; \\ Kazumi Nishino16; Masashi Mikubo ${ }^{17}$; Tomoyuki Yokose ${ }^{18 ;}$ Hirotoshi Dosaka-Akita19
}

\begin{abstract}
MET, a proto-oncogene located in $7 \mathrm{q} 21$ q31, encodes a receptor tyrosine kinase, of which mutations, amplification, fusions and overexpression are reported to be associated with oncogenesis. MET exon 14 (METex14) skipping is one of such MET alterations, and this abnormality is caused by genetic deletions or mutations in the intron/exon boundary sites as splice-site abnormalities, resulting in the generation of a deleted transcript in exon 14. This exon encodes juxtamembrane domain, which contains the binding site of c-Cbl E3 ubiquitin ligase. Therefore, lack of METex14 suppresses
\end{abstract}

ubiquitination and degradation, which lead to functional MET activation. In 2020, tepotinib and capmatinib were approved for the treatment of advanced recurrent lung cancer with this alteration. To implement the molecular testing to detect METex14 skipping in clinical practice, a practical guidance was released from the Biomarker Committee of the Japan Lung Cancer Society, and the content is introduced in this article.

(JJLC. 2021;61:361-370)

KEY WORDS — Lung cancer, MET exon 14 skipping, Biomarker test, Companion diagnostic test

\section{Introduction}

In 2020, tepotinib and capmatinib were approved for the treatment of advanced recurrent lung cancer with METex14 skipping, and their companion diagnostics are ArcherMET and FoundationOne CDx, respectively. Although FoundationOne CDx has been introduced as a comprehensive genomic profiling test, ArcherMET is the companion diagnostic agent first in Japan, and the required number of unstained sections and its requirements are slightly different from those of commonly used Oncomine DxTT. The Biomarker Committee of the Japan Lung Cancer Society has released a series of practical guidance to biomarker testing, including an overview of the genetic abnormality and their clinical relationship, for biomarkers for lung cancer treatment.
1Department of Diagnostic Pathology, National Cancer Center Japan; ${ }^{2}$ Department of Thoracic Oncology, National Cancer Center Hospital East, Japan; ${ }^{3}$ Research Division of Genome Companion Diagnostics, Hokkaido University Hospital, Japan; ${ }^{4}$ Division of Hematology, Respiratory Medicine and Oncology, Department of Internal Medicine, Saga University, Japan; ${ }^{5}$ Center for Innovative Cancer Treatment, Tokyo Medical and Dental University, Japan; ${ }^{6}$ Department of Palliative Medicine, Tohoku University School of Medicine, Japan; ${ }^{7}$ Division of Clinical Cancer Genomics, Hokkaido University Hospital, Japan; ${ }^{8}$ Department of Respiratory Medicine, Kanazawa University, Japan; ${ }^{9}$ Division of Respiratory Medicine and Rheumatology, Department of Multidisciplinary Internal Medicine, Tottori University, Japan; ${ }^{10}$ Department of Thoracic On- cology, Hyogo Cancer Center, Japan; 11Department of Thoracic Oncology, Aichi Cancer Center Hospital, Japan; ${ }^{2}$ Department of Laboratory Medicine, National Cancer Center Hospital, Japan; 13Department of Pathology, Kansai Medical University, Japan; 14Department of General Thoracic Surgery, Breast and Endocrinological Surgery, Okayama University, Japan; 15Department of Genome Biology, Kindai University, Japan; 16Department of Thoracic Oncology, Osaka International Cancer Institute, Japan; ${ }^{17} \mathrm{De}-$ partment of Thoracic Surgery, Kitasato University School of Medicine, Japan; 18Department of Pathology, Kanagawa Cancer Center, Japan; ${ }^{19}$ Department of Medical Oncology, Faculty of Medicine and Graduate School of Medicine, Hokkaido University, Japan.

Corresponding author: Yasushi Yatabe. 


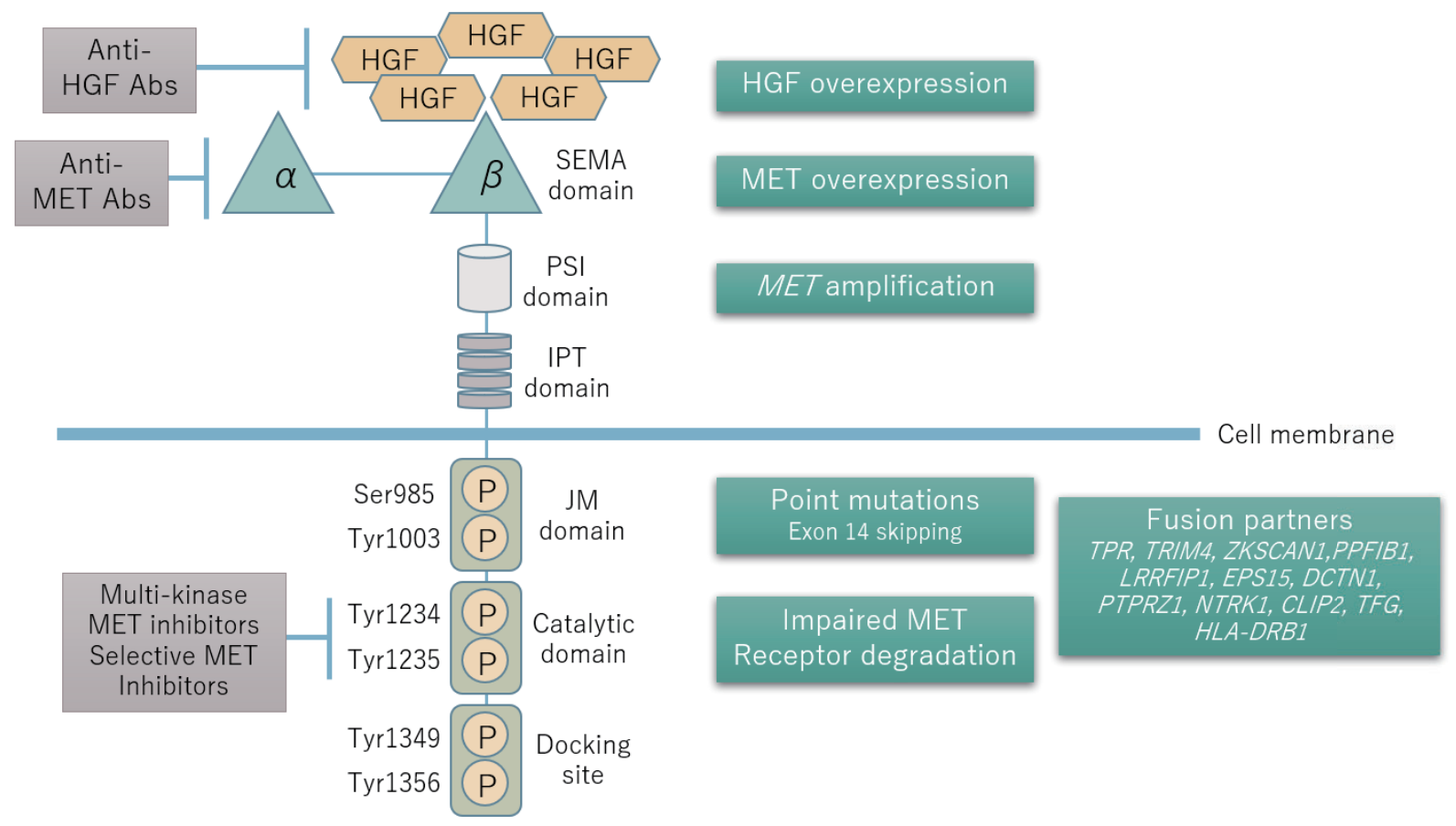

Figure 1. MET and its ligands HGF function and its abnormalities and outline drugs for it.

This time, we have published a practical guide on METex14 skipping testing. We believe that it will be helpful for the member of the Japan Lung Cancer Society.

\section{MET genes and MET exon 14 skipping (METex 14 skipping)}

\subsection{MET oncogene}

$M E T$, a proto-oncogene located in 7q21-q31, encodes a receptor tyrosine kinase that leads to the RAS/MAPK, Rac/Rho, PI 3 K/AKT signaling pathway activation. These pathways, when deregulated, are known to be involved in tumor growth, anti-apoptosis, and metastasis (Figure 1). ${ }^{1}$ MET amplification and overexpression are typically observed in several carcinomas (including colorectal cancer, gastric cancer, liver cancer, sarcoma) and are also found in up to $4 \%$ of adenocarcinomas and circa $1 \%$ of squamous cell carcinomas in lung cancer. ${ }^{2}$ Specifically targeting this gene amplification and overexpression, a humanized antibody was tested in clinical trials, but sufficient efficacy was not demonstrated in the phase III clinical study. ${ }^{3}$ On the other hand, it has been reported that $M E T$ amplification is acquired as one of the resistance mechanisms to EGFR-TKI treatment, ${ }^{4}$ and currently EGFR-TKI and MET inhibitor are investigated as treatment methods. ${ }^{5}$ In addition, the MET gene mutations have also been reported in small cell lung cancer, ${ }^{6}$ and the mutations in the specific intronic regions of MET gene could result in METex14 skipping in which exon 14 is not transcribed, ${ }^{7}$ a phenomenon that has gained attention as MET inhibitors were developed.

\subsection{METex 14 skipping*}

In addition to the deletion of whole METex14 itself, short genetic deletions or mutations in the intron/exon boundary sites as splice-site abnormalities, resulting in the generation of a deleted transcript in exon 14 (Figure 2). Such abnormalities are called METex14 skipping.

METex14 encodes juxtamembrane domain, and is the site containing the binding site of c-Cbl E3 ubiquitin ligase. For this reason, it is believed that the absence of METex 14 suppresses ubiquitination and degradation, resulting in the activation of MET. Mutations in MET Y1003 that are critical for this ubiquitination also cause degradation defects comparable to those of METex 14

* MET exon 14 skipping is a phenomenon occurring in RNAs and proteins, and various designations exist for mutations in genes that cause splicing abnormalities. In this guidance, MET exon 14 was used as a METex14 to describe more accurately what kind of abnormalities (METex14 skipping, METex14 deletion, METex14 mutations) were later described. 


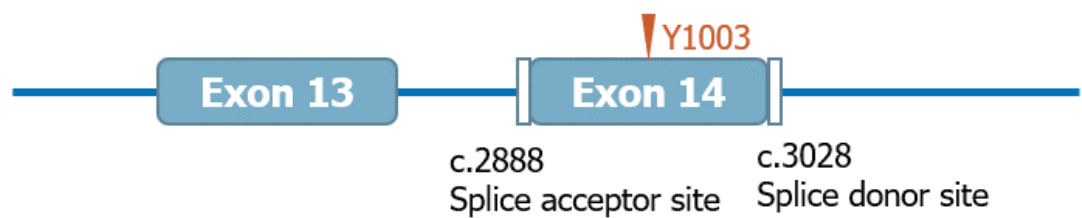

\begin{tabular}{|lcc|}
\hline METex14 alterations & Base substitution & Indel \\
\hline Splice donor sites & $149(49.1 \%)$ & $42(13.8 \%)$ \\
\hline Splice acceptor sites & $4(1.3 \%)$ & $100(32.9 \%)$ \\
\hline Noncoding regions adjacent splice acceptor & $4(1.3 \%)$ & $3(1.0 \%)$ \\
\hline Whole exon 14 deletion & $2(0.7 \%)$ \\
\hline
\end{tabular}

Figure 2. Distributions of genetic abnormalities resulting in METex14 skipping, based on the published data (PMID: 27343443).

skipping ("functional analogue”). 8,9 By this degradation defect in the protein, abnormal clustering occurs and, together with the gene amplifications described below, are known to be associated with overexpression on immunostaining. $8,10,11$

METex14 skipping is observed for approximately 3\% to $4 \%$ of lung adenocarcinomas, is more common in older adults, and is not associated with gender or tobacco use. They are also mutually exclusive from other driver mutations (EGFR, ALK, ROS1, BRAF, KRAS, and HER2). Tumors exhibiting METex14 skipping are known to be associated with high frequency of MET copy-number gains and gene-amplification,8,10,11 and histologies other than pulmonary adenocarcinoma, and are known to be more frequent in sarcomatoid carcinomas. 8,12

\section{MET-tyrosine kinase inhibitors}

\subsection{Types of MET-tyrosine kinase inhibitors for METex 14 skipping}

A summary of currently known small molecule METtyrosine kinase inhibitors for METex 14 skipping is listed in Table $1 .^{13}$ Among these, tepotinib (brand name: TEPMETKO) has been approved on November 19, 2019 through "Sakigake Designation Scheme", based on Phase II clinical study, VISION study. ${ }^{14}$ Capmatinib (brand name: TABRECTA) has been approved on June 4, 2020 based on GEOMETRY mono-1 study. ${ }^{15}$ All studies are conducted for tumors with METex 14 skipping mutations, including both mutation sites (splice acceptor site, splice donor site, whole-exon 14 deletion) and muta- tion types (indels, point mutations) to evaluate treatment efficacy. ${ }^{14,15}$

\subsection{About VISION study}

VISION study was conducted on patients with unresectable, advanced or recurrent non-small cell lung cancer (NSCLC) positive for METex14 skipping mutation. This was a multinational, open-label, single-arm, phase II study to evaluate the antitumor efficacy, tolerability, and safety of tepotinib $500 \mathrm{mg}$ once daily in patients. ${ }^{14}$ The primary endpoint was the response rate, which was 42.4\% (95\% confidence interval: 32.5-52.8) in 99 patients evaluated for efficacy based on RECIST ver 1.1.

\subsection{About GEOMETRY mono-1 study}

GEOMETRY mono-1 study was an international, openlabel, single-arm, phase II study of patients with unresectable, advanced or recurrent NSCLC positive for METex14 skipping mutation. ${ }^{15}$ Twenty-eight chemotherapy-naïve patients in cohorts $5 \mathrm{~b}$, and 69 patients with prior chemotherapy in cohort 4 received 400 mg capmatinib orally twice daily. Response rates (based on RECIST ver 1.1 criteria) assessed by the independent imaging institution as the primary endpoint were $67.9 \%$ (95\% confidence interval: $47.6-84.1$ ) for $5 \mathrm{~b}$, and $40.6 \%$ (95\% confidence interval: 28.9-53.1) for cohort 4, respectively.

\section{METex14 skipping diagnostic testing}

\subsection{ArcherMET}

In VISION study, target patients were identified by “Oncomine Focus Assay" from tissue samples, and by 
Table 1. Therapeutic Agents Targeting METex14 Skipping

\begin{tabular}{|c|c|c|c|c|c|c|c|}
\hline Compound & $\begin{array}{l}\text { Approval in } \\
\text { Japan }\end{array}$ & Company & Targets & $\begin{array}{l}\text { Type of } \\
\text { inhibitor }\end{array}$ & $\begin{array}{l}\text { Enzyme } \\
\text { IC50, } \\
\text { nM }\end{array}$ & $\begin{array}{l}\text { Clinicaltrials.gov } \\
\text { NCT number } \\
\text { /EuDraCT number }\end{array}$ & $\begin{array}{l}\text { Reference } \\
\text { (PMID) }\end{array}$ \\
\hline Capmatinib & $\begin{array}{c}\text { Approved } \\
(2020 / 6 / 29)\end{array}$ & Novartis & MET & Type Ib & 0.13 & $\begin{array}{l}\text { NCT02750215 } \\
\text { NCT01324479 }\end{array}$ & 21918175 \\
\hline Tepotinib & $\begin{array}{c}\text { Approved } \\
(2019 / 11 / 19)\end{array}$ & Merck & MET & Type Ib & 3 & $\begin{array}{c}\text { NCT02864992/2015- } \\
\text { 005696-24 }\end{array}$ & 23553846 \\
\hline Savolitinib & Not approved & $\begin{array}{c}\text { AstraZeneca/ } \\
\text { Hutchison }\end{array}$ & MET & Type Ib & 5 & NCT02897479 & 25148209 \\
\hline AMG337 & Not approved & $\begin{array}{c}\text { China } \\
\text { Meditech } \\
\text { Amgen/Nanbio }\end{array}$ & MET & Type Ib & 1 & $\begin{array}{l}\text { No current clinical } \\
\text { trials }\end{array}$ & 27196782 \\
\hline Cabozantinib & Not approved & Elexis & MET & Type II & 1.3 & NCT01639508 & 21926191 \\
\hline Glesatinib & Not approved & Mirati & $\begin{array}{c}\text { VEGFR2, } \\
\text { RET, KIT, } \\
\text { TIE-2, AXL } \\
\text { MET, VEGFR }\end{array}$ & Type II & 1 & NCT02544633 & $\begin{array}{c}\text { Cancer Res } \\
\text { 2012; } 72, \\
\text { S8: Abstr } 1790\end{array}$ \\
\hline Merestinib & Not approved & $\begin{array}{c}\text { Therapeutics } \\
\text { Lilly }\end{array}$ & $\begin{array}{c}\text { RON, TIE-2 } \\
\text { MET, TIE-1, } \\
\text { AXL, ROS1, } \\
\text { DDR1/2, } \\
\text { FLT3, } \\
\text { MERTK, } \\
\text { RON, } \\
\text { MKNK1/2 }\end{array}$ & Type II & 4.7 & NCT02920996 & 23275061 \\
\hline
\end{tabular}

“Guardant360" from plasma cfDNA. The analytical validation of ArcherMET for which tissues and blood can be examined on the same platform was confirmed and subsequently ArcherMET was approved as companion diagnostics in Japan. ArcherMET, the companion diagnostics test for tepotinib, is a next-generation sequencing (NGS) assay performed using the Illumina MiSeq Dx instrument, using molecular barcodes and a new anchored multiplex PCR technology (Figure 3). The test is performed on RNA extracted from a tissue sample and on cfDNA from plasma. The only cfDNA companion diagnostics approved to date is the Cobas v.2.0 EGFR T790M assay, which is reimbursed. Notably, ArcherMET based NGS analysis for cfDNA implies a more substantial workload compared to Cobas.

\subsubsection{Specimen used}

As shown in Figure 4, an unstained specimen (containing $\geq 10 \%$ tumor cells, a total of $20 \mathrm{~mm}^{2}$ tumor surface area, and $\geq 10 \mathrm{ng}$ of RNA) is required to initiate the test. For an example, in a sample with tumor content of $10 \%$ or more, if the tissue is $2 \mathrm{~mm}^{2}$ on the $\mathrm{H} \& \mathrm{E}$ slide, at least
10 unstained slides are necessary. A minimum of $10 \mathrm{ng}$ RNA of input is required to run the test, the same amount as required by Oncomine DxTT. For blood, at least $10 \mathrm{ml}$ of blood must be drawn into PAXgene cfDNA blood collection tube.

\subsection{FoundationOne CDx (F1CDx)}

In GEOMETRY mono-1 study, the testing assay used for the clinical trial was based on the RT-PCR method and performed by a central laboratory facility. Upon its analytically cross validation with the data collected in this study, FoundationOne CDx has been approved as companion diagnostics test. The analysis of METex 14 skipping by FoundationOne CDx is performed by detecting splice site mutation/deletion near exon 14. For specific commentary, please refer to the Japan Lung Cancer Society Guidance for Multiplex Gene-Panel Testing Using Next Generation Sequencers in Patients with Lung Cancer, version 1.1.16

\subsection{Reimbursement}

ArcherMET: Can only be calculated once per patient to select tepotinib therapy for patients with NSCLC. 

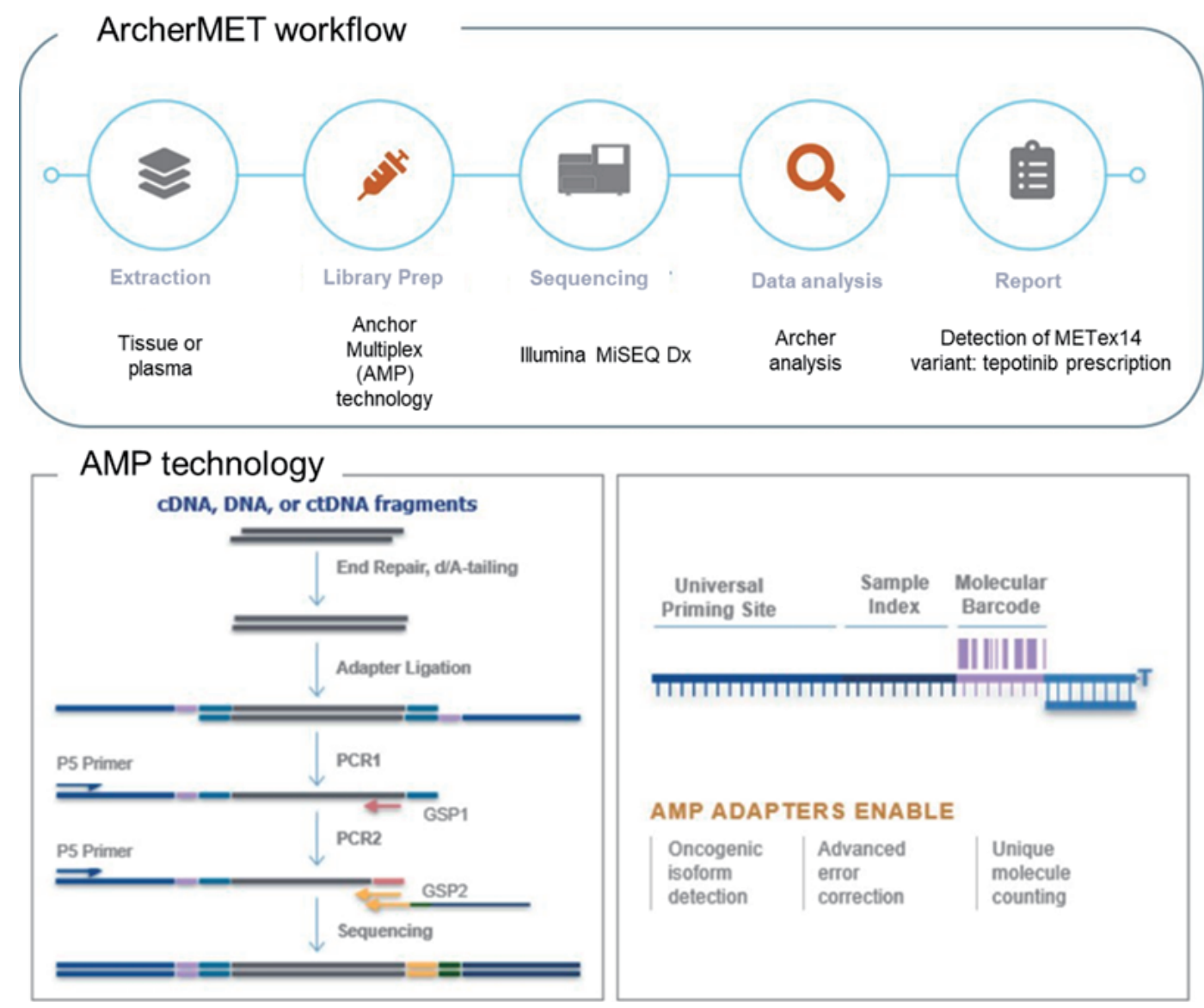

Figure 3. ArcherMET workflow and anchored multiplex (AMP) technology to characterize.

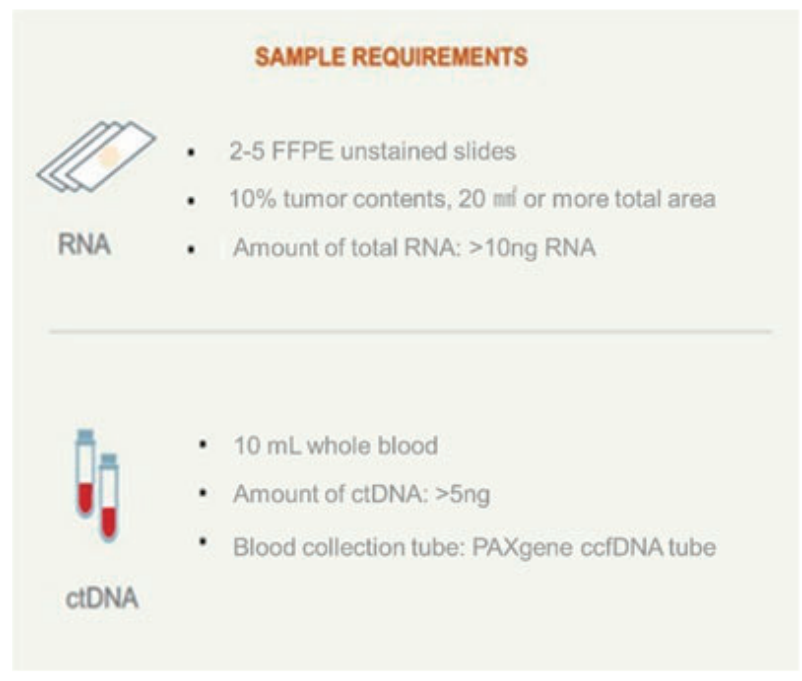

Figure 4. Specimens used in ArcherMET and their requirements.

- ArcherMET by tissue: 5,000 points

- ArcherMET by plasma: 5,000 points (only when tis- sue ArcherMET is difficult to obtain)

FoundationOne CDx: When used as a diagnostics test, exclusively the companion diagnostics component is reimbursed. As a result, there is a substantial discrepancy between the amount that the company bills to ordering hospital and the collected reimbursement, resulting in a substantial burden to the hospitals finance, something that makes FoundationOne CDx test virtually difficult to be used. ${ }^{16}$

\subsection{Considerations for reimbursement points}

In case of concurrent use with Oncomine DxTT in the same month can be interpreted as billable based on the partial revision of "Practical Considerations Associated with Partial Revision of Calculation Methods for Medical Fees" etc. When performed concurrently with other individual genetic tests, the points should be calculated according to the number of tested items (i.e. specific biomarker). For lung cancer, the points for EGFR, ALK, ROS1, and KRAS are classified as "easy to process": 2 items $=4,000$ points, 3 items $=6,000$ points; and points 
Table 2. Combinations of Likely Practical Examinations and Their Characteristics

\begin{tabular}{|c|c|c|c|c|c|c|c|c|}
\hline \multirow{2}{*}{$\begin{array}{l}\text { Driver } \\
\text { Mutations testing } \\
\text { algorithm }\end{array}$} & \multicolumn{4}{|c|}{ Primary test } & \multirow{2}{*}{\multicolumn{2}{|c|}{$\begin{array}{l}\text { Secondary } \\
\text { test } \\
\text { MET }\end{array}$}} & \multicolumn{2}{|c|}{ Assessment } \\
\hline & EGFR & $A L K$ & ROS1 & $B R A F$ & & & Benefits & Disadvantage \\
\hline $\begin{array}{l}\text { \#1 Simultaneous } \\
\text { multiple gene } \\
\text { testing }\end{array}$ & $\begin{array}{c}\mathrm{qPCR} \\
\text { (Cobas, } \\
\text { TheraScreen) }\end{array}$ & $\begin{array}{c}\text { IHC or } \\
\text { FISH }\end{array}$ & $\begin{array}{l}\text { qRT-PCR } \\
\text { (Amoy } \\
\text { ROS1) }\end{array}$ & $\begin{array}{c}\text { NGS } \\
\text { (ODxTT } \\
\text { BRAF) }\end{array}$ & $\begin{array}{c}\text { NGS } \\
\text { (ArMET) }\end{array}$ & - & $\begin{array}{l}\text { EGFR, ALK; short } \\
\text { TAT }\end{array}$ & $\begin{array}{l}\text { - Since this testing } \\
\text { algorithm requires } \\
\text { the largest amount of } \\
\text { tumor sample, it may } \\
\text { not be possible to } \\
\text { perform all the tests } \\
\text { with small specimens. } \\
\text { - Be aware of when } \\
\text { certain points are } \\
\text { rounded off, and } \\
\text { therefore taken out } \\
\text { on reimbursement } \\
\text { points. }\end{array}$ \\
\hline $\begin{array}{l}\text { \#2 Simultaneous } \\
\text { multiplex gene } \\
\text { testing }\end{array}$ & & is $\left(O D x^{\prime}\right.$ & T multi) & & $\begin{array}{c}\text { NGS } \\
\text { (ArMET) }\end{array}$ & - & $\begin{array}{l}\text { All CDx results are } \\
\text { available at once, } \\
\text { facilitating treatment } \\
\text { selection. }\end{array}$ & $\begin{array}{l}\text { - Be aware of when } \\
\text { certain points are } \\
\text { rounded off, and } \\
\text { therefore taken out } \\
\text { on reimbursement } \\
\text { points. }\end{array}$ \\
\hline $\begin{array}{l}\text { \#3 Simultaneous } \\
\text { multiplex gene } \\
\text { testing followed } \\
\text { by MET testing } \\
\text { if ODxTT } \\
\text { positive }\end{array}$ & & is $\left(O D x^{\prime}\right.$ & T multi) & & - & $\begin{array}{c}\text { NGS } \\
\text { (ArMET) }\end{array}$ & $\begin{array}{l}\text { In some cases, it } \\
\text { may be possible to } \\
\text { consider the use of } \\
\text { residual RNA after } \\
\text { implementation of } \\
\text { ODxTT multi, etc. }\end{array}$ & $\begin{array}{l}\text { - Longer TAT but } \\
\text { better cost perfor- } \\
\text { mance. }\end{array}$ \\
\hline
\end{tabular}

Table 3. Comparisons of 96 Specimens from the VISION Study in Which Plasma and Tissue Samples from the Same Patients Were Evaluated Using ArcherMET

\begin{tabular}{lccc}
\hline & & \multicolumn{2}{c}{ Tissue } \\
& & METex14+ & METex14- \\
\hline \multirow{2}{*}{ Plasma } & METex14+ & 18 & 1 \\
& METex14- & 19 & 58 \\
\hline
\end{tabular}

for BRAF, NTRK and MET are classified as "complicated to process": 2 items $=8,000$ points, 3 items or more $=$ 12,000 points can be calculated.

Plasma ArcherMET testing should include a medical justification supporting the request in the medical record and in a fee-for-service statement, something that can be applied only when tissue ArcherMET testing is difficult to obtain for medical reasons. Plasma testing is allowed only once per patient. However, the use of this plasma test should be consistent with plasma EGFR tests, so plasma ArcherMET tests cannot be reimbursed during the same month when lung cancer tissue ArcherMET tests are performed. Plasma ArcherMET tests can therefore be submitted and reimbursed in the following month, but cannot be recommended in situations as described below.

\section{Positioning of METex14 skipping testing in ge- netic testing for lung cancer}

Given the high response rates of MET inhibitors, treatment strategy must be based on appropriate mutation profile in all NSCLC patients, including EGFR, ALK, ROS1 and BRAF. Table 2 summarizes the combinations of gene tests that might be carried out at present, and with their main characteristics.

For ArcherMET in the combinations \#2 and \#3 in Table 2 , it is conceivable to consider plasma testing, notwithstanding a medical justification explaining why the histological examination cannot be performed. Notably, the results of 96 samples used in the VISION study analyzed by ArcherMET for both tissue and plasma (Table 3), ${ }^{17}$ highlight that the plasma test was only able to detect half of the METex14 skipping patients observed using the tissue test. Therefore, plasma tests should be carefully considered. Negative results may not be conclusive in regard to tepotinib treatment eligibility (see 3.4 Considerations for reimbursement points).

In Oncomine DxTT, the analysis algorithms identify 


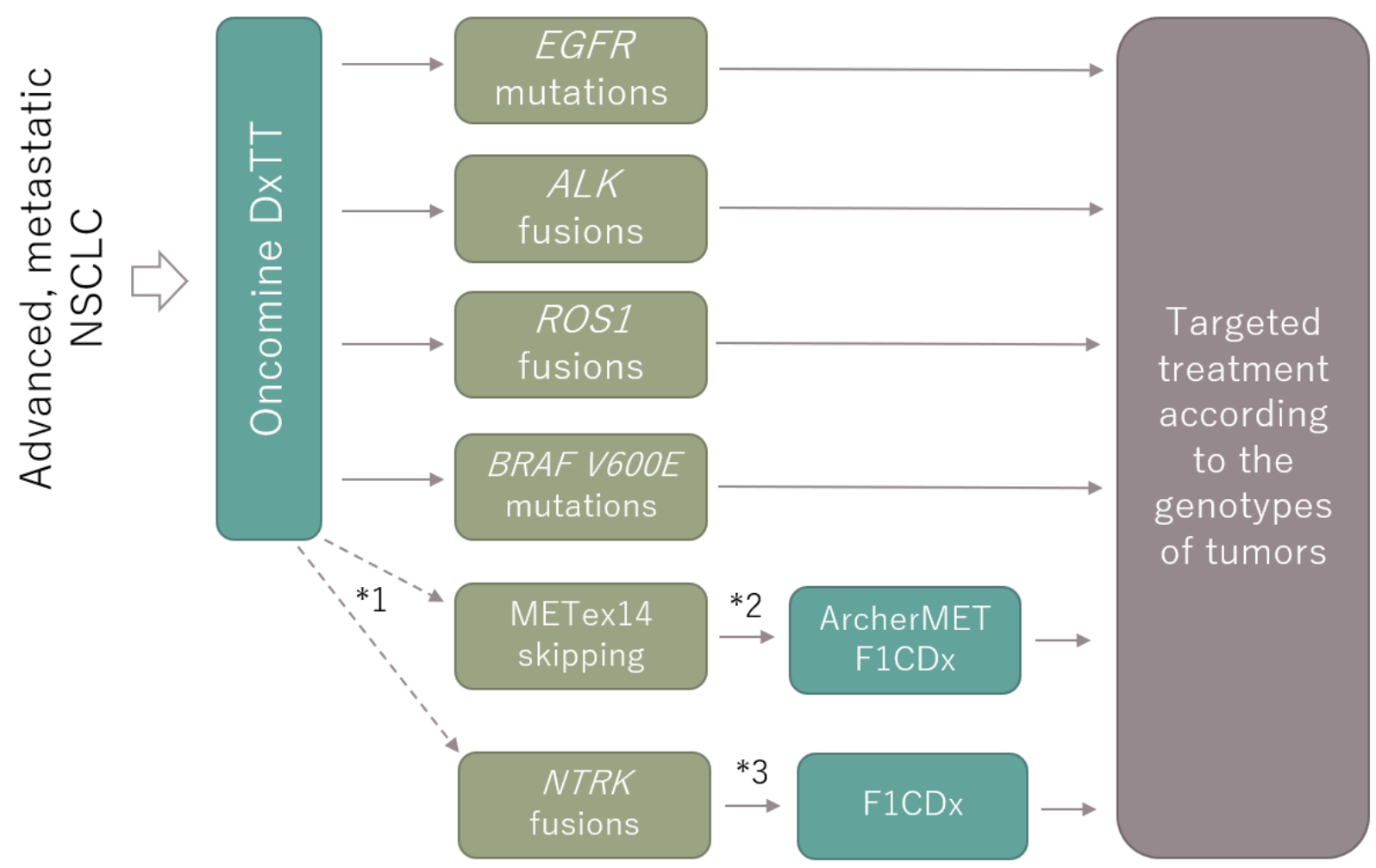

Figure 5. Algorithm for molecular targeted treatment of advanced recurrent non-small cell carcinoma in Japanese insurance practices. As discussed below, testing with Oncomine DxTT is recommended because individual genetic testing is associated with facility-take-out costs. If companion-diagnostic abnormalities in EGFR, ALK, ROS1 and BRAF are found, treatment based on molecular abnormalities can be initiated as such. *1 METex14 skipping, NTRK fusion gene are detectable in Oncomine DxTT but returned as reference when requested by physicians for study purposes, although ArcherMET and F1CDx, a companion diagnostic test, is implemented. *2 Re-biopsy may be considered appropriate in cases of significant tissue depletion due to Oncomine DxTT and difficult to submit to ArcherMET. Alternatively, plasma testing may be performed, keeping in mind that positive results may be low. *3 F1CDx is used as a companion diagnostic for METex14 skipping and NTRK fusion gene, large differences in test costs and fee-for-service arise.

METex 14 skipping in RNA and MET intron-exon boundaries in DNA. Positive agreement (PPA) was 93.88\% and negative agreement (NPA) was $98.33 \%$ between "Oncomine Focus Assay" (the used assay in VISION clinical trial study) and ArcherMET, the approved companion diagnostics test.

While the "Oncomine Focus Assay" is not the same assay as the Oncomine DxTT, one should know that it is the underlying assay based on which the Oncomine DxTT was developed on, and uses the same principles and technology. Although a proper analytical validation should be conducted, it is conceivable to use the companion diagnostics ArcherMET only in cases where the Oncomine DxTT is performed and positive for METex14 considering the actual reimbursement setting
(Figure 5). We also would hope to expect the reimbursement system to approve the use of METex 14 results from Oncomine DxTT by a panel of cancer genomics medicine experts as described below.

Conversely, there are cases where the results cannot be obtained with the Oncomine DxTT due to specimen features, etc. In such cases, testing should be performed, referring to "the Guidance for Multiplex Gene-Panel Testing with Next Generation Sequencers in Lung Cancer Patients, version 1.1".16 Notably, while for NTRK, screening with immunohistochemistry (IHC) is recommended for lung cancer, ${ }^{18}$ and some papers have suggested the possibility of using MET IHC as a simple screening method also for detecting METex 14 skipping, ${ }^{19,20}$ IHC cannot be recommended at this time based 


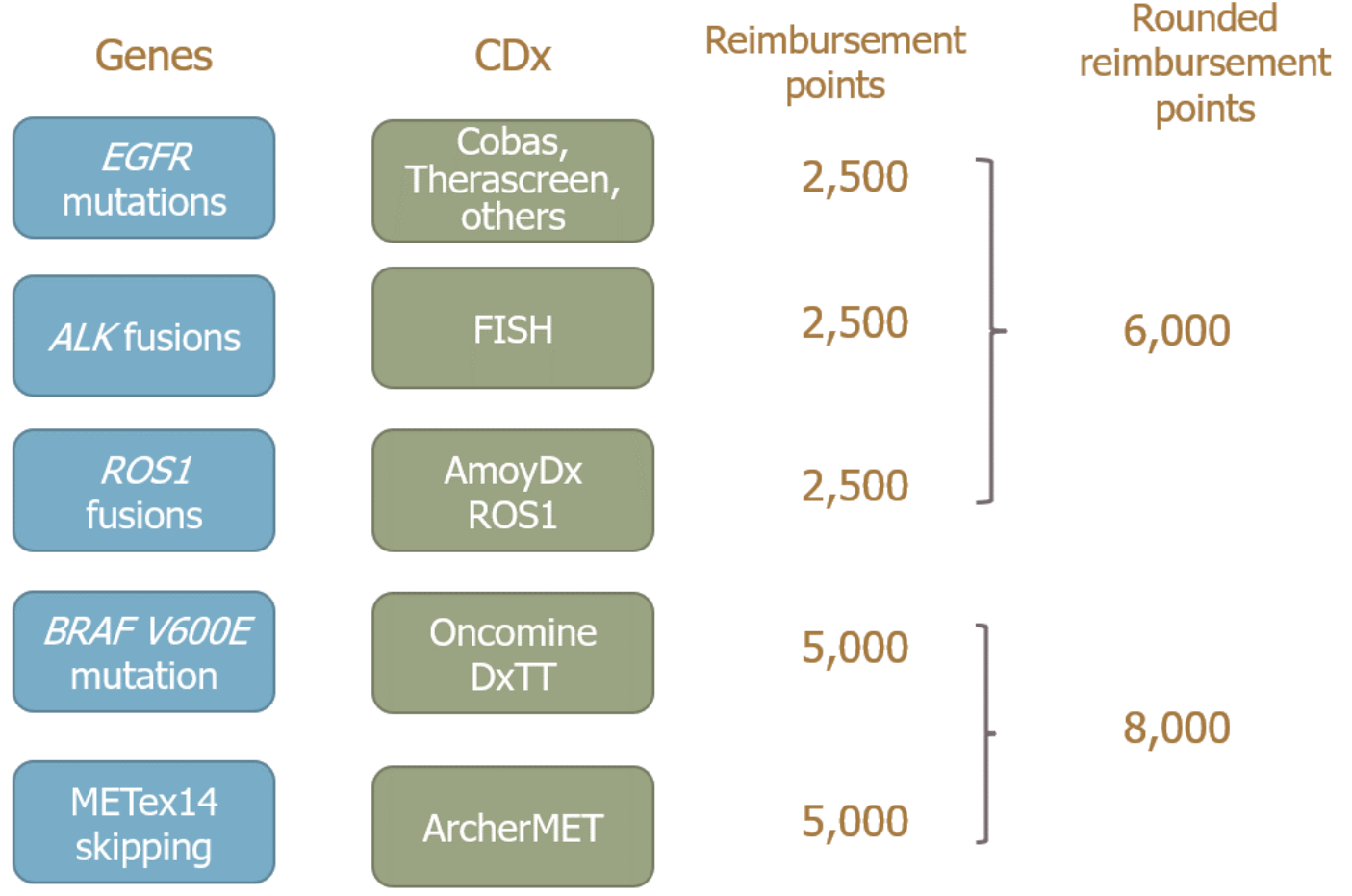

Figure 6. Fee-for-service by number of test items. In April 2020, the number of test items was revised based on medical remuneration. Currently, clinical laboratories are not compliant with this revision, resulting in a deficit of 1,500 points for EGFR, ALK and ROS1. In addition to these tests, BRAF gene test and METex14 skipping test are treated as separate items and round off a certain number of points, resulting in a deficit of 2,000 points. Therefore, if EGFR, ALK, ROS1, BRAF and MET gene tests are performed separately, the total deficit may reach 3,500 points.

on the published compelling negative reports. ${ }^{14,21}$

Although many medical institutions currently perform sequential single biomarker testing, when EGFR, $A L K$, ROS1 and BRAF tests are performed separately, a number of reimbursement points can be rounded up to a certain point, which, for reimbursed treatment, is 6,000 plus 5,000 points (Figure 6). However, many testing companies do not take this point cap into account, and if the price is not negotiated, the company would be charging 7,500 points plus 5,000 points, resulting in an additional deficit of 1,500 points. On top, if METex 14 skipping is added, the price difference goes up to 3,500 points, and the deficit increases significantly.

In response to this situation, the Japan Lung Cancer Society has submitted a request to the Ministry of Health, Labor and Welfare (MHLW) to allow insurance reimbursement for the drug if the results of the Oncomine DxTT multi-system are deemed appropriate for use of the drug by an Expert Panel (Molecular Cancer Board) of Cancer Genomic Medicine. ${ }^{22}$

\section{Conclusions}

In addition to EGFR, $A L K$, ROS1 and BRAF, therapeutic agents for METex14 skipping have emerged, and their companion diagnostics have been introduced. In particular, the addition of cfDNA analysis by NGS to insurance coverage is a significant step, and its further expansion is desirable. Currently, since METex14 skipping can also be detected by Oncomine DxTT, it will be essential and desirable to perform at first this multiplex genetic test. This is because most tumor specimens obtained from advanced or recurrent lung cancer are small, and it is often difficult to examine these 5 genes individually with a sequential gene testing approach. In addition, if individual genetic tests are performed, a certain number of reimbursement points are rounded off, resulting in a net financial deficit, something that makes increasingly necessary to shift to testing practice towards a multiplex genetic testing-based approach. For all above mentioned and although ArcherMET and FoundationOne CDx companion diagnostics tests are enforced by the current 
health care regulation, in spite the fact that METex 14 skipping alteration is already detectable by the Oncomine DxTT, we suggest that such clinically unreasonable regulations need to be improved.

本論文内容に関連する著者の利益相反 : 谷田部恭 [日当・講 演料］アストラゼネカ [研究費・助成金などの総額］アストラ ゼネカ, 中外製薬, Archer DX Inc, サーモフィッシャー, 日 本電気, 後藤功一 [日当・講演料]ノバルティスファーマ株式 会社, 松本慎吾 [日当・講演料] ノバルティスファーマ [研究 費・助成金などの総額］中外製薬，MSD，イーライリリー, メルク，ノバルティス，畑中 豊 [日当・講演料]アストラゼ ネカ株式会社, ノバルティスファーマ株式会社, ファイザー株 式会社, 日本 MSD 合同会社 [研究費 ·助成金などの総額] シ スメックス株式会社, 株式会社理研ジェネシス, サーモフィッ シャーサイエンティフィック株式会社, 株式会社 DNA チッ プ研究所，ロシュ・ダイアグノスティックス株式会社，日本 MSD 合同会社, 大鵬薬品工業株式会社 [企業などが提供する 寄附講座]シスメックス株式会社, 大鹏薬品工業株式会社, 株 式会社エスアールエル, 合同会社みらか中央研究所, 荒金尚子 [研究費・助成金などの総額］Boehringer Ingelheim［奨学 （奨励）寄附金などの総額] Chugai, Taiho, Ono, Eli Lilly, 井上 彰 [日当・講演料]アストラゼネカ, イーライリリー, 里内美弥子 $[$ 日当・講演料 $]$ 日本イーライリリー, ファイザー, アストラゼネカ, 中外製薬, 大鵬薬品工業, ノバルティス, $\mathrm{MSD}$, 小野薬品工業, ブリストルマイヤーズスクイブ, 武田 薬品工業, メルクバイオファーマ[研究費・助成金などの総 額]MSD 株式会社, ヤンセンファーマ, アムジェン, IQVIA, 武田薬品工業, ファイザー, アストラゼネカ, 中外製薬, ノバ ルティス, ブリストルマイヤーズスクイブ, Abbvie, 蔦 幸 治［日当・講演料］MSD［旅費，贈答品などの受領］小野製 薬, 豊岡伸一 [日当・講演料] 中外製薬株式会社 [奨学 (奨励) 寄附金などの総額 $]$ 大鵬薬品工業株式会社, アステラス製薬株 式会社，西尾和人 [日当・講演料] 中外製薬，エーザイ，日本 ベーリンガー，アストラゼネカ［研究費・助成金などの総額］ Ignyta, Inc., 日本イーライリリー, 日本ベーリンガー, 韓国大 塚製薬, TORG, NEJSG, 国立病院機構大阪南医療センター, ニチレイバイオサイエンス，西野和美 [日当・講演料 $]$ 中外製 薬，ノバルティス，秋田弘俊 [奨学 (奨励) 寄附金などの総額 $]$ 大鵬薬品工業, 小野薬品工業, 日本イーライリリー

\section{REFERENCES}

1. Liang H, Wang M. MET Oncogene in Non-Small Cell Lung Cancer: Mechanism of MET Dysregulation and Agents Targeting the HGF/c-Met Axis. Onco Targets Ther. 2020;13:2491-2510.

2. Cancer Genome Atlas Research Network. Comprehensive molecular profiling of lung adenocarcinoma. Nature.
2014;511:543-550.

3. Spigel DR, Edelman MJ, O’Byrne K, Paz-Ares L, Mocci S, Phan S, et al. Results From the Phase III Randomized Trial of Onartuzumab Plus Erlotinib Versus Erlotinib in Previously Treated Stage IIIB or IV Non-Small-Cell Lung Cancer: METLung. J Clin Oncol. 2017;35:412-420.

4. Engelman JA, Zejnullahu K, Mitsudomi T, Song Y, Hyland C, Park JO, et al. MET amplification leads to gefitinib resistance in lung cancer by activating ERBB3 signaling. Science. 2007;316:1039-1043.

5. Scagliotti G, Moro-Sibilot D, Kollmeier J, Favaretto A, Cho EK, Grosch H, et al. A Randomized-Controlled Phase 2 Study of the MET Antibody Emibetuzumab in Combination with Erlotinib as First-Line Treatment for EGFR Mutation-Positive NSCLC Patients. J Thorac Oncol. 2020;15:80-90.

6. Maulik G, Kijima T, Ma PC, Ghosh SK, Lin J, Shapiro GI, et al. Modulation of the c-Met/hepatocyte growth factor pathway in small cell lung cancer. Clin Cancer Res. 2002;8: 620-627.

7. Kong-Beltran M, Seshagiri S, Zha J, Zhu W, Bhawe K, Mendoza N, et al. Somatic mutations lead to an oncogenic deletion of met in lung cancer. Cancer Res. 2006;66: 283-289.

8. Awad MM, Oxnard GR, Jackman DM, Savukoski DO, Hall D, Shivdasani P, et al. MET Exon 14 Mutations in Non-Small-Cell Lung Cancer Are Associated With Advanced Age and Stage-Dependent MET Genomic Amplification and c-Met Overexpression. J Clin Oncol. 2016;34: 721-730.

9. Frampton GM, Ali SM, Rosenzweig M, Chmielecki J, Lu $\mathrm{X}$, Bauer TM, et al. Activation of MET via diverse exon 14 splicing alterations occurs in multiple tumor types and confers clinical sensitivity to MET inhibitors. Cancer Discov. 2015;5:850-859.

10. Paik PK, Drilon A, Fan PD, Yu H, Rekhtman N, Ginsberg MS, et al. Response to MET inhibitors in patients with stage IV lung adenocarcinomas harboring MET mutations causing exon 14 skipping. Cancer Discov. 2015;5:842849.

11. Tong JH, Yeung SF, Chan AW, Chung LY, Chau SL, Lung RW, et al. MET Amplification and Exon 14 Splice Site Mutation Define Unique Molecular Subgroups of Non-Small Cell Lung Carcinoma with Poor Prognosis. Clin Cancer Res. 2016;22:3048-3056.

12. Liu X, Jia Y, Stoopler MB, Shen Y, Cheng H, Chen J, et al. Next-Generation Sequencing of Pulmonary Sarcomatoid Carcinoma Reveals High Frequency of Actionable MET Gene Mutations. J Clin Oncol. 2016;34:794-802.

13. Reungwetwattana T, Liang Y, Zhu V, Ou SI. The race to target MET exon 14 skipping alterations in non-small cell lung cancer: The Why, the How, the Who, the Unknown, and the Inevitable. Lung Cancer. 2017;103:27-37.

14. Paik PK, Felip E, Veillon R, Sakai H, Cortot AB, Garassino MC, et al. Tepotinib in Non-Small-Cell Lung Cancer with MET Exon 14 Skipping Mutations. $N$ Engl J Med. 2020;383:931-943.

15. Wolf J, Seto T, Han JY, Reguart N, Garon EB, Groen $\mathrm{HJM}$, et al. Capmatinib in MET Exon 14-Mutated or 
MET-Amplified Non-Small-Cell Lung Cancer. $N$ Engl $J$ Med. 2020;383:944-957.

16. Yatabe Y, Sunami K, Goto K, Nishio K, Aragane N, Ikeda $\mathrm{S}$, et al. Multiplex gene-panel testing for lung cancer patients. Pathol Int. 2020;70:921-931.

17. Package insert of ArcherMET Dx. 2020. Available from: https://archermet.jp/wp-content/uploads/2020/06/\%E 6\%B7\%BB\%E4\%BB\%98\%E6\%96\%87\%E6\%9B\%B8.pdf

18. Naito Y, Mishima S, Akagi K, Igarashi A, Ikeda M, Okano S, et al. Japan society of clinical oncology/Japanese society of medical oncology-led clinical recommendations on the diagnosis and use of tropomyosin receptor kinase inhibitors in adult and pediatric patients with neurotrophic receptor tyrosine kinase fusion-positive advanced solid tumors, cooperated by the Japanese society of pediatric hematology/oncology. Int J Clin Oncol. 2020; 25:403-417.

19. Gow CH, Hsieh MS, Wu SG, Shih JY. A comprehensive analysis of clinical outcomes in lung cancer patients harboring a $M E T$ exon 14 skipping mutation compared to other driver mutations in an East Asian population. Lung Cancer. 2017;103:82-89.

20. Zheng D, Wang R, Ye T, Yu S, Hu H, Shen X, et al. MET exon 14 skipping defines a unique molecular class of nonsmall cell lung cancer. Oncotarget. 2016;7:41691-41702.

21. Guo R, Berry LD, Aisner DL, Sheren J, Boyle T, Bunn PA Jr, et al. MET IHC Is a Poor Screen for MET Amplification or MET Exon 14 Mutations in Lung Adenocarcinomas: Data from a Tri-Institutional Cohort of the Lung Cancer Mutation Consortium. J Thorac Oncol. 2019;14: 1666-1671.

22. The Japan Lung Cancer Society and The Japan Lung Cancer Patients Federation. Request for the use of expert panels in MET/NTRK genetic diagnosis of lung cancer. 2020. Available from: https://www.haigan.gr.jp/ modules/important/index.php?content_id $=50$ 